\title{
GENRE VIOLENCE PREVENTION AND COLLECTIVE EFFICACY IN YOUNG WOMEN FROM VIOLENT CONTEXTS
}

\author{
Сара-Maprapiтa ЧАВЕС-ВА $\triangle \mathrm{b}, \mathrm{EC}$ \\ ПРОФІЛАКТИКА НАСИЛЬСТВА І КОЛЕКТИВНА ЕФЕКТИВНІСТЬ \\ У МОЛОДИХ ЖІНОК ВІД НАСИЛЬНИЦЬКИХ СИТУАЦІЙ
}

The objective of the research was to design, implement and evaluate a psychological program to support women exposed to gender violence, and mitigate the risk factors and affective physical damage in order to contain the scale of levels of social anxiety and perceived risk, promoting a proactive coping in the cognitive behavioral field, as an option to vulnerability, encouraging and developing social effectiveness. It was aimed at women aged 17 to 21 , administered out in a weekend mode for 11 weeks in a 6-hour workshop mode basis during a scholar year, evaluating the effects on perceived risk (risk cognition), social anxiety, affective coping, physiological coping, empowerment and social agency, (the latter subcrucial factors around citizen culture).

The study has as a background a program that promoted pro-social behavior, social agency and citizen culture in young people of the same age range, in this study an intervention was designed and addressed with sample of men and women from 17 to 21 years, with the purpose to control social violence through the eradication of collective fears, proactive coping (more rational and less reactive) and promotion of citizen culture (Chávez-Valdez y Esparza-del Villar, 2018).
Quoting Durán (2017). A study conducted by Mexicans against Corruption and Impunity (MCCI), in partnership with the International Center for Journalists (ICFJ) reveals that by 2017, an average of seven women killed a day because of gender violence, and also warned that there was a lack of unification and legal loopholes that do not allow gender violence to be punished forcefully, which results in 20 percent of the violent murders against women, they are not recognized as femicides, since in the period from 2012 to June 2016, 9,581 women were murdered in the Mexican Republic.

Based on these reports, at least 7,694 women were shot dead, quartered, raped, suffocated or beaten to death and in turn, were not recognized as victims of femicide (Durán,2017).

In this understanding, gender violence is a type of abuse that gradually undermines the well-being, freedom and dignity of women, causing them psychological, physical and social health conditions by holding them hostage from fear, isolating them from social assistance and progressively being exposed to a re victimization when uncontrolled and see destroyed all their spheres of personal and professional life, sometimes reaching 
suicide or homicide to be severely exposed to violence with a low risk cognition.

Regarding collective efficacy, ValenzuelaAguilera (2012), strives to define it as one that interrelates with social cohesion and mutual trust with the shared disposition (social agency) to intervene in the maintenance of social control. Collective efficiency is instrumental in obtaining a specific effect and implies a sense of proactive commitment (of citizen participation) that the community assumes as understood.

Social agency is defined by Bandura (2001), from a psychosocial field as that ability of a person or group to function in their environment, an agent is an individual that connects with the immediate social structure.

Also, it would be expected that citizen participation and agency, sub factors of collective efficacy, affect their risk cognition, since, awareness and prevention would lead to self-care and protection, as well as a decrease in aggressions and violence in its micro and macro environment, communities will remain united and proactive towards the reach of a social lifestyle that contains and condemns violence and is a multiplier of social change, adapting and promoting family projects that add to the community project with a focus on promotion of the culture of prevention, welfare and social health.

Vulnerability, as Chambers (1989) clarifies, is repeatedly defined as a synonym for poverty, subject to gender bias, caste or socioeconomic levels, while in a perceived sense, it is more the result of different dimensions of deprivation such as: physical disadvantage, isolation, and low levels of empowerment and the permanent "exposure to risks, contingencies, shocks, and stress" with serious effects on a defense learned as a collective, where the individual is perceived as lacking tools to face everyday situations, without manage to control losses and be even more violated.

For authors like Wievorka (2001), the most obvious danger of the victims is to fall into victimhood, not to become autonomous and constructive subjects, and proactive groups with the empowerment to leave a vicious circle of victimhood and reactivate their sense of social agency and generate a change in their own lives, and change proactively their families and communities.
Accordingly, the prevention of gender-based violence could be based on the understanding of promoting those factors that improve collective efficiency and reduce risk factors, as well as reaffirm citizen culture in women who are or are perceived as vulnerable in areas of high violence and machism or sexism (violence against women).

\section{Problem Statement}

Regarding public health and victimization, from a psychosocial perspective, we identify social fear as a feeling of diffuse social anxiety that affects women, understood as an emotional fear and perceived risk as an ambivalent factor that is also theoretically understood as a cognitive fear, which in healthy societies multiply protection and self-care habits, but that, in environments of high social violence confuses and erodes health and well-being, since coping strategies are based on those of emotional and physiological nature, instead of those more cognitive and behavioral that lead to rationalize, adapt and generate social agency with a sense of resilience, resulting in havoc in the health and women life quality, also in terms of community health gradually derives in social damage, emphasizing especially in those communities and groups resentful of the vulnerability and violence.

It is proposed that coping strategies in women victims of gender-based violence are based on strategic components of emotional and physiological coping, which denote increasing, participation, collective efficacy and citizen culture can be encouraged to avoid paying a culture of vulnerability, and there is an emotional fear or social anxiety, likewise, there is a perception of low risk in the current cycle of gender violence due to the institutionalization of violence in women from contexts with high insecurity.

\section{Objective}

The general objective of the study is to promote the development of the group, identify and analyze beliefs-perceptions-negative attitudes, promote proactive coping strategies (cognitive behavioral positive), decrease social anxiety elevation of cognition-perception of risk (such as social fear factors), and with that, to influence the physical 
and emotional coping related to the emotional and perceived wear of fear, thus promoting collective efficacy through endemic factors of the same through promoting the social agency and participation of women by granting them a opportunity to change their condition of helplessness learned by decentralizing the victim in a passive condition (victim) to experience through collective intervention-treatment their levels of social agency (active subject) under the premise of the need to support other women by reducing their levels of social anxiety as a group, encouraging collective empathy generating high levels of empowerment.

The treatment was a process that required the approach, implementation and analysis of various risk elements that are theoretically indicated as associated to the gestation and permanence of a high incidence of gender violence in order to obtain a solution to a social need specifically for those female collectives.

\section{Hypothesis Statement}

Hil: There will be a significant difference between the measures of perceived risk (risk cognition), citizen culture (social agency and citizen participation), emotional and physiological coping strategies, around social anxiety (emotional / diffuse fear), intra subjects, and the measures after the intervention in the group of women under pre and posttest treatment.

Hol: There will not be a significant difference between the measures of perceived risk (risk cognition), citizen culture (social agency and citizen participation), emotional and physiological coping strategies, around social anxiety (emotional / diffuse fear), intra subjects, and the measures after the intervention in the group of women under pre and posttest treatment.

$H i 2$ : There will be a significant difference between the measures of perceived risk (risk cognition), citizen culture (social agency and citizen participation), emotional and physiological coping strategies, around social anxiety (emotional / diffuse fear), inter subjects, and the measures between the treatment group and the women of the control group.

Ho2: There will not be a significant difference between the measures of perceived risk (risk cognition), citizen culture (social agency and citizen participation), emotional and physiological coping strategies, around social anxiety (emotional / diffuse fear), inter subjects, and the measures between the treatment group and the women of the control group.

The intervention consisted of the design, implementation and evaluation of a Saturday workshop during the school year, in a university of the City of Chihuahua. The proposal used various techniques: creative play, development of prosocial agency and behavior, communication, effective cooperation, theatrical (emotional) expression, ethnographic poetry, conflict management and emotional stability, elements of the self-concept construct, personality traits, as well., addressed other stimulation techniques for effective coping, cognitive behavioral and reduction or management of physio-affective strategies, through discussion and debate forums, and relaxation techniques in the control of social anxiety also balancing risk cognition I develop care and selfprotection skills, empathy and personal growth.

\section{Participants}

The sample consisted of 66 women in the late adolescence stage, with an age range of 17 to 21 years, distributed in a treatment group of 33 people, while another group of 33 women performed the control condition, in total there were 66 Women participating in the study. Women belong to a medium-low socioeconomic and cultural stratum. A random selection of the participants was made in addition to all the young women signed an informed consent after receiving information and presentation of the program by the researchers, in this study there were no cases of sample mortality during the intervention process and its evaluation in the city of Chihuahua, Chih, Mexico.

\section{Design and process}

The study used a quasi-experimental methodology, a design of repeated pre-treatment-post-test measures with a control group (see table 1). In the first stage, during the first sessions, specialists in the area of psychology applied diagnostic instruments to measure the promotion factors. and risk on which it is hypothesized that the program would generate satisfactory significance and effect size, in a complementary way a semi-structured inter- 


\begin{tabular}{|c|c|c|c|}
\hline Groups & & & \\
\hline & Pre- Test (Ex ante) & Treatment & Post-Test (Ex post) \\
\hline Experimental & $O_{t 1 \text { (treatment) }}$ & $X\left(_{\text {intervention })}\right.$ & $O_{t 2} \quad$ (treatment) \\
\hline \multicolumn{4}{|l|}{$($ Treatment $)(T G)=33$} \\
\hline \multicolumn{4}{|l|}{ participants } \\
\hline \multicolumn{4}{|l|}{ Control $(C G)=33$} \\
\hline participants & & & $O_{c 2} \quad$ (control) \\
\hline
\end{tabular}

Nota: $O_{t 1}=$ treatment group pre-test, $O_{t 2}=$ treatment group post-test, $O_{c 2}=$ control group Source: own elaboration.

view was conducted to measure the type and degree of victimization to which they have been exposed, to determine their participation in the dynamics of the various group sessions, in order to define victim and non-victim groups in each of the intervention sessions, it was requested to indicate the types of violence to which they have been exposed in personal and family settings, narrating everyday situations and recurring of their daily life, where they were described: emotional reactions such as: personal issues, perceptions, feelings, as well as logging of their physiological reactions, explicitly to be able to provide greater explanation of the psycho-physical emotional vulnerabilities, but also of their abilities and talents, pay in an environment of trust and trust. group change based on deep relaxation techniques.

The Intervention program was developed in 11 teaching sessions, a total of 66 hours of workshop on: "Prevention of Gender Violence and Collective Efficiency in Young Women of Violent Contexts", with young women of public higher education in Chihuahua city, Chihuahua, Mexico.

A treatment group composed of young women aged 17 to 21 years, of higher public education, was compared with a control group of women of the same age range and of homogeneous psychosocial characteristics. The intra-subjects' differences of the treatment were analyzed in a first stage in the first and second time, pre and post, and in a second stage, the differences between treatment participants and control group were analyzed, in the Ex post time (posttest).

The women participating in the control group, of socio-demographic and age characteristics similar to the treatment group, were selected for convenience, considering that the schedules in which they were attending, failed to accommodate those of those who participated in the intervention workshop, this sample was collected in the same geographical area, in the same study center, and with subjects under the same conditions, to which the battery of scales that was used with the treatment sample was applied, in the second time (post test).

The workshop consisted of activities distributed in thematic sessions, with sessions focused on: eradicating the perception of vulnerability and cognitive distortions, collective fear (social anxiety and perceived risk), and increasing collective efficacy, promoting proactive behavioral cognitive coping in groups infiltrated by social violence. These modules were: 1) vulnerability, ability/talent and 
empowerment), 2) emotional physical regulation (relaxation techniques), 3) understanding, management and expression of collective fears, 4) cognitive control of episodes of anger, sadness and joy, 5) proactive behavioral cognitive coping (reasoned action vs. reaction), 6) community health cooperation and promotion relationships through the development of a quality of life promotion program for women victims of violence.

It was managed, through group sessions after each topic, to inquire about emotional fear or social anxiety and risk cognition among women; As well as the coping strategies that women use, to offer guidelines or action strategies, in order to prevent the escalation of the current level of social violence.

\section{Scales}

For the taking of measurements, validated selfreport measures were used and for the development of the course and qualitative support, semistructured interviews were conducted regarding victimization, with additional descriptive information thrown by the discussion groups, group sessions of participatory evaluation, exposures and resolution of group cases.

The coping strategies were measured through: Urban Security Questionnaire (CIU) developed by Dr. Roxana Vuanello, from the National University of San Luis, Argentina, in 2006. Compiles responses or reactions pertaining to coping: affective, cognitive, physiological and behavioral, so you can get a score for each of them. In this study we focus on obtaining the partial evaluation scores of the physiological and emotional confrontations of the stressors related to the victims of violence. This instrument was designed based on a version of the Inventory of Anxiety Situations and Responses (ISRA) by Miguel Tobal and Cano Vindel in 1997 (Vuanello, 2006). In a study conducted by ChavezValdez et al (2018), an internal consistency of 0.90 was obtained, which indicates that it was reliable.

The measures of perceived risk of victimization and the social anxiety scale, also known as: concrete and diffuse fear, were both developed by José Ignacio Ruiz, Phd in 2007.

Perceived Risk Scale for Victimization (concrete fear) (Ex ante- Ex post), Ruiz (2007)

Proposes an evaluation through a list of 17 crimes, sub-scale developed and adapted from
Peńa (2005), on a Likert-type scale, with three points ranging from: unlikely (1), probable (2) or very likely (3); referring to the probability of each of the following crimes occurring in the future: the probability of being a direct or indirect victim in the next twelve months.

Crimes such as: sexual assault, persecution, disappearance or homicide are included. From the sum of the responses to each of the items and dividing the result by the total of reagents a perceived risk score is obtained, where, a higher score, indicates a higher perceived risk of victimization (Ruiz, 2007), In a previous study within the same location, with young people of the same age range of both genders, Chavez-Valdez et al (2018) obtained a reliability index of 0.96 .

\section{Social anxiety scale (emotional / diffuse fear) (Ex ante- Ex post).}

It consists of a list of 7 items, prepared by Ruiz (2010), Likert scale, with response options, from: 1 (nothing) to 4 (much). It results from the combination of a group of three items on diffuse fear from Ruiz (2004), adapted with two items from the International Victimization Survey, plus another item on fear within the home. These three items obtained a cronbach alpha of 0.78 (Ruiz, 2004). The other three items refer to the degree of fear regarding the colony, and the municipality (Peńa, 2005). In the last research carried out in 2019, for the city of Chihuahua, Chih. Mexico, the scale reported a Cronbach's alpha of $=0.92$.

Citizen culture scale (Ex ante-Ex post): composed of indicators, such as: affective identification, commitment to the city, social agency, respect for the city, city services, citizen participation, respect for social norms, citizenship and tolerance. The internal reliability index of the scale showed a Cronbach's alpha of 0.97, in a sample applied in the city of Chihuahua.

\section{First analysis phase}

\section{Results}

The differences between treatment subjects and control group are evaluated, in the second time (post), see Table 2 .

After performing the $\mathrm{T}$ Test for related samples, differences in statistically significant pre and post test scores were identified, and Hol (null hypo- 
" $T$ " test for related samples and results of the scores obtained on the scales in the Pre and Post, of the treatment group.

\begin{tabular}{ll}
\hline Scale & $T$ - test Result \\
\hline Specific Fear ( risk cognition/perceived risk) & $t(32)=4.35 p=.000$ \\
Social Anxiety (widespread fear) & $t(32)=9.45, p=.000$ \\
Affective coping strategies & $t(31)=3.16, p=.000$ \\
Physiological coping strategies & $t(32)=5.37, p=.000$ \\
Citizen culture & $t(32)=7.24, p=.001$ \\
\hline
\end{tabular}

Note: Specific Fear= woman risk perception, Widespread Fear= crime emotional fear, Affective coping strategies= emotional coping traits between woman suffering violence, Physiological coping strategies= physiological somatization of genre violence, Cognitive coping: strategies and cognitions about dealing with genre violence, Citizen Culture $=$ civic participation aspects, respect and affectivity for the city, social agency and enrollment with civic norms. Source: own elaboration.

thesis) in the main variables is rejected, for total perceived risk (risk cognition) $\mathrm{t}(32)=4.35, \mathrm{p}=.000$, citizen culture $\mathrm{t}(32)=7.24, \mathrm{p}=.001$, social anxiety (emotional $/$ diffuse fear) total $\mathrm{t}(32)=9.45, \mathrm{p}=.000$, affective coping strategy $\mathrm{t}(31)=3.16, \mathrm{p}=.000$, physiological coping strategies $\mathrm{t}(32)=5.37, \mathrm{p}=.000$.

The treatment showed variation in the measures of physiological affective responses, which in extreme degrees denote some features of posttraumatic stress in women; as well as, a statistically significant difference in the means of the components of the measures of collective efficacy, among others, such as the social agency and citizen participation of women who were under treatment.

\section{Second analysis phase}

We worked with a control group of $\mathrm{N}=33$ women at the level (post test), the results were compared with those obtained by the Ex post treatment group (post test). The results of the control and treatment groups are analyzed below, by analysis of variance (Anova) of one factor, see

\section{Table 3.}

The perceived risk (risk cognition) $\mathrm{F}(1.64)=2.73$, $\mathrm{p}<.001, \mathrm{~d}=1.02$, shows statistically significant differences between treatment and control, with high effect size, citing Cohen (1992), the effects 0.20 are low, 0.50 are moderate and the effects of 0.80 or more are considered high effects.
In the case of the citizen culture factor, we found an F $(1.64)=-7.28 p<.001$, Cohen's $d=2.99$, shows significant variation between treatment and control group, with large effect size.

Regarding social anxiety, emotional fear shows $\mathrm{F}(1.64)=51.11 \mathrm{p}<.001$, Cohen's $d=1.70$, that is, there are statistically significant differences between treatment and control groups, with a high effect size.

Analyzing the coping strategies shows changes in statistically significant measurements in the affective coping responses $\mathrm{F}(1.64)=3.90 \mathrm{p}=.002$, Cohen's d $=1.42$, between treatment and control group, in relation to the strategies or physiological responses with an $\mathrm{F}(1.64)=-16.77 \mathrm{p}=<.001$, Cohen's $d=1.14$, both show statistically significant differences in mean scores between pre and post test and with high effect size.

Therefore, Ho2 (null hypothesis) is rejected because in fact statistically significant differences were found between the sample under treatment and the group of women who were within the control group.

The need to guarantee the results of the investigation is to assume the lowest possible margins of Type I error, and at the same time Type II. According to Cohen (1992) an effect of 0.20-0.49 is low, from 0.50 to 0.79 they are medium or moderate and those effects from 0.80 onwards are large. 
Means, Standard deviations and results of the variance análisis one way (ANOVA), comparative between treatment and control group in the second time (post)

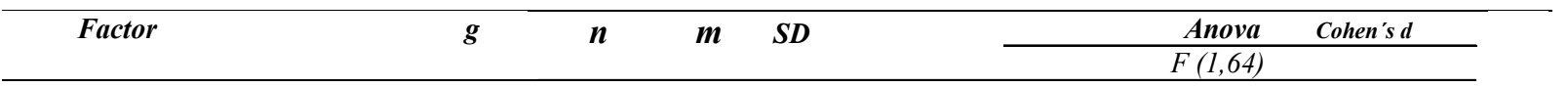

Specific Fear

$\begin{array}{llllllll} & \boldsymbol{t} & 33 & 26.33 & 2.16 & & \\ \text { Perceived risk }(+) & \boldsymbol{c} & 33 & 23.47 & 3.54 & F(1,64)=2.73 \quad p<.001 & 1.02 \\ & & & & & & \\ \text { Citizen culture }(+) & \boldsymbol{t} & 33 & 11.20 & 3.47 & F(1.64)=-7.28 p<.001 & 2.99 \\ & \boldsymbol{c} & 33 & & & & & \end{array}$

Widespread Fear

$\begin{array}{lllllll} & \boldsymbol{t} & 33 & 15.45 & 1.98 & \\ \text { /Social anxiety (-) } & \boldsymbol{c} & 33 & 21.58 & 5.24 & F(1,64)=51.11 p<.001 & 1.70\end{array}$

$\begin{array}{lllllll} & \boldsymbol{t} & 33 & 7.87 & 5.32 & F(1,64)=3.90 p=.002 & 1.42 \\ \text { Affective coping strategies (- ) } & \boldsymbol{c} & 33 & 12.27 & 4.18 & \end{array}$

$\begin{array}{rrrrrrr} & \boldsymbol{t} & 33 & 13.08 & 3.33 & \\ & & & & & & \\ \text { Physiological coping strategies (-) } & \boldsymbol{c} & 33 & 17.42 & 4.26 & F(1,64)=-16.77 p=<.001 & 1.14\end{array}$

\footnotetext{
Nota: $g=$ group, $t=$ treatment, $c=$ control, Perceived risk= woman risk cognition en; Social anxiety $=$ emotional fear/ widespread fear; Affective coping strategies $=$ woman emotional coping traits respect genre violence, Physiological coping strategies $=$ woman physical somatization traits of genre violence $;$ Citizen culture $=$ social agency aspects, civic participation, city norms and rules affectivity, Cohen's d= (effect size of the treatment) Source: own elaboration
}

In the first stage of analysis, the association between subjects in the first time (pre-test) and second time (post-test) of the sample of women under treatment was reviewed by $\mathrm{T}$ test (related measures), finding significant changes in factors of risk encompassed in the social anxiety constructs and in the emotional and physiological responses, which in extreme degrees denote traits of posttraumatic stress and in the perceived risk, better associated with a sense of risk cognition in these women than in these cases by the level Submission to gender violence usually tends to normalize the cycle of violence, they even feel guilty of being victims of the aggressor, they have no control over their lives and show mixed feelings, because for the moment a risk reappreciation was required, this allowed them to experience their "risk awareness". 
The social agency and participation of women in group, presented variation between time (Ex ante) and second time (Ex post), for the group of women who were during 66 hours of intervention. After the intervention, greater agency and social control were found, as well as, more assertive responses around conflicting social situations, progress in their ability to recognize feelings and states of anxiety, helplessness and more sense of control over emotions and behaviors of young women involved in the treatment.

From the beginning, in summary, it was intended to level the levels of emotional and physiological coping, as well as a greater and better social agency and participation in women.

A more proactive coping was achieved, high levels of anxiety or emotional fear were attenuated and risk perception or cognition rose.

A promotion in self-care and protection behaviors was observed in the face of the vulnerability of their immediate contexts. Even so, the perception of proactive risk was raised in the face of constant threat, reducing social anxiety; coupled with a progress in emotional physical exhaustion that led to much wear and tear in relationships, and greater social agency and social effectiveness in these women, coupled with this, high rates of perception of risk in the family environment were identified seemed to be associated with traits of post-traumatic stress in these groups of women exposed to violence, violating their well-being, health and quality of life, and in their proactivity: connectivity and sociability.

The results of the treatment show a satisfactory impact of the program since the women in the treatment group show statistically significant differences in: 1) an increase in assertive abilities such as expressing their feelings, giving and receiving support, identification and control of self-destructive behaviors of personality, show empathy, proactive interaction, maintain and end conversations, that is to say greater efficiency in the eradication of passive behaviors with other women, a larger social agency, this corroborates us that the activities of collaborative dynamics between equals stimulate pro sociability and Socio-emotional development in young women.

The adaptation of the resources learned during each of the sessions was followed and they were asked for feedback at the end of each session and in the final projects for the improvement and promotion of quality of life, called: "communities free of violence", and this in order to replicate the learning to immediate peers in their various spheres of personal influence and rationalize the risk to which they are scalarly exposed to generate greater self-care and protection behaviors.

This study validates the program for adolescent women aged 17 to 21 , and proposes a psychological treatment support that reduces social anxiety, raises cognition and risk awareness, and fosters the development of citizen culture in women subjected to gender-based violence in violent contexts It should be considered for future research that the present study has limitations, as is the case that there was only one treatment group and one control group for budgetary reasons, and in the case of replication, the inclusion of At least two other groups, one more in the treatment condition and another in the control condition, the test is required in larger samples, which reinforces the experimental design in the future, and allows establishing causal relationships, another limitation is the use of self-report reports, as this represents biases, this could be improved by measuring these exchange effects thrown into the intervention supported by additional evaluations with other family members, neighbors or student / workmates and other Associated variables such as: selfesteem, cognitive and emotional intelligence and resilience.

\section{REFERENCES}

Bandura, A. (2001). Social cognitive theory: An agentic perspective. Annual Review of Psychology, 52, 1-26. The Agency (1956). Describes the form of agency.

Chambers, R. (1989). Editorial Introduction: Vulnerability, Coping and Policy. IDS Bulletin 20(2): 1-7.

Chávez-Valdez, S.M. y Esparza-del Villar, O.A. (2018). Manejo De Miedo, Estrategias De Afrontamiento Y Cultura Ciudadana Para Prevención De La Violencia. European Scientific Journal. 14(5), e-ISSN 1857-7431, doi: 10.19044/ esj.2018.v14n5p133, 133-149.

Cohen, J. (1992). A Power Primer. Psychological Bulletin, 112, 155-159.

Feixa, C. (1998). De jóvenes, bandas y tribus. Antropología de la juventud. Barcelona: Ariel.

Gómez, C.E. (2008). Adolescencia y familia: revisión de la revisión y la relación y la comunicación como factores de riesgo o protección. Revista Intercon- 
tinental de Psicología y Educación, 10 (2), 105-122.

Durán, V (2017). Las muertas que no se ven: el limbo de los feminicidios. Mexicanos contra la corrupción e impunidad, A.C. Recuperado en Línea en: http://contralacorrupcion.mx/web/femimicidiosocultos. Fecha de publicación: 23 de febrero del 2017.

Nińo, S., Lugo, N., Rozo, C. y Vega, L. (1998). Territorios del miedo en Santafé de Bogotá: imaginarios de los ciudadanos. Bogotá: TM Editores y Observatorio de Cultura Urbana.

Peńa, M. (2005). Conducta antisocial. Factores de riesgo y de protección. Tesis doctoral. Universidad Complutense de Madrid.

Ruiz, J.I. (2007). Cultura ciudadana, miedo al crimen y victimización: un análisis de sus interrelaciones desde la perspectiva del tejido social. Acta Colombiana de Psicología.

Ruiz, J.I. (2010). Eficacia Colectiva, Cultura Ciudadana y Victimización. Acta Colombiana de Psicología, Bogotá, Colombia.13(1), 26-29.

Santos, J.I., Villa, M.J.P., García, A., León, G., Quezada, S. \&Tapia, R. (2003). La transición epidemiológica de las y los adolescentes en México. Salud pública en México, 45 (1), 140-152.

Valenzuela-Aguilera, A. (2012). La eficacia colectiva como estrategia de control social del espacio barrial: evidencias desde Cuernavaca, México. Revista INVI, 27(74), 187-215.

Villareal, A. y Silva, B.F.A. (2006). Social cohesion, criminal victimization and perceived risk of crime in Brazilian neighborhoods. Social Forces, 84 (3), 1725-1753.

Vozmediano, L. y San Juán, C. (2006). Empleo de Sistemas de Información Geográfica en el estudio del Miedo al Delito. Revista Espańola de Investigación Criminológica. 2 (4) www.criminologia.net. (recuperado el 26 de octubre del 2014).

Vuanello, R. (2006). Un nuevo instrumento de Evaluación Psicológica: El Cuestionario de Inseguridad Urbana. Interdisciplinaria, 23, 1:17-45.

Wieviorka, M. (2001) La violencia: Destrucción y constitución del sujeto. Espacio Abierto, vol. 10, núm. 3, julio-septiembre, 2001, Universidad del Zulia Maracaibo, Venezuela.

\section{АНОТАЦІ9}

\section{Сара-Мартаріма Чавес-Вальдес.}

Профілактика насильства і колективна ефективність у молодих жінок від насильницьких ситуацій.

Програма втручання з жінками, жертвами гендерного насильства, розроблена і спрямована на оцінку впливу соціальної ефективності шляхом аналізу: сприйняття, відчуття та несприятливої поведінки, які впливають на їхнє здоров'я та знижують якість їх життя. Були використані саморегульовані групові методики. Вибірка складалася з 66 жінок, у віковому діапазоні від 17 до 21 року, 33 жінки в групі лікування та 33 жінки контрольної групи. Дана робоча група була створена для виявлення факторів ризику та просування стратегій подолання для дієвої адаптації. Для цього ми працювали з квазі-експериментальним дизайном використовуючи повторні заходи: очікувані (попереднє тестування) - втручання - фактичні (заключний тест) з контрольною групою. Він проводився у вихідний протягом 11 тижнів у 6-годинному режимі робочої групи, загалом 66 годин. Спрямовані просоціальні стратегії втручання, що враховують фактори ризику, ендемічні аспекти насильства, серед інших, модуляцію негативних когнітивних та поведінкових процесів та фізіо-афективні реакції, позначені таким чином, що призводять до ризику еволюції індивідуальної патології, яка зазвичай призводить до депресивних процесів, узагальнюють тривожність, хронічний стрес та посттравматичний характер.

Програма зазнала суттєвих змін, що визначаються аналізом відхилення та ослаблення до високих ефектів, продемонстрованих D Коена, відмінності в до та після лікування в про-соціальних аспектах, у термінах факторів ризику, серед інших, у негативних когнітивних та поведінкових процесах та фізіо-афективних реакціях, що формують риси синдрому загальної тривоги та посттравматичного стресу у молодих жінок.

Ключові слова: стратегії подолання, соціальна тривожність, сприйнятий ризик, ефективність колективу, культура громадян.

\section{ANNOTATION}

\section{Sarah-Margarita Chavez-Valdez.}

Genere violence prevention and collective efficacy in young woman from violent contexts.

An intervention program with women victims of gender violence is designed and addressed evaluating effects on social effectiveness by analyzing: perceptions, sensations and adverse behaviors that have an impact on their health and reduce their quality of life. Self-regulated group techniques were used. The sample consisted of 66 women, in the age range of 17 to 21 years, 33 women in the treatment group and 33 women in the control group. A workshop was designed to identify risk factors and promote coping strategies for proactive adaptation. For this effect, we worked with a quasi-experimental design using repeated measures, Ex ante (pretest)-intervention-Ex post (posttest), with a control group. It was carried out in a weekend mode for 11 weeks in a 6-hour workshop mode, a total of 66 hours. The intervention addressed pro-social strategies considering risk factors, endemic aspects of violence, among others, modulation of negative cognitive and behavioral processes and of physio-affective responses labeled to lead at risk to the evolution of 
individual pathologies that normally lead to depression processes, generalized anxiety, chronic stress and post trauma nature.

The program exerted significant changes determined by the analysis of variance and of moderate to high effects demonstrated by Cohen's d, the differences in pre and post-treatment means in pro-social aspects, in terms of risk factors, among others, in the Negative cognitive and behavioral processing and physio-affective responses that shaped traits of generalized anxiety, and post-traumatic stress in young women.

Keywords: coping strategies, social anxiety, perceived risk, collective efficacy, citizen culture.

Рецензенти:

А. психол. н., проф. Болтівець С.І., д. психол. н., проф. Раку I.

Надійшла до редакції 21.01.2020.

Підписана до друку 21.02.2020.

Бібліографічний опис для цитування:

Chavez-Valdez S.M. Genere violence prevention and collective efficacy in young woman from violent contexts. Психологія і суспільство. 2020. №2. С. 98-107. DOI: https://doi.org/ 10.35774/pis2020.02.098 